\title{
How Transformational Leadership predicts Employees' Affective Commitment and Performance
}

\author{
Neuza Ribeiro * \\ CARME - Centre of Applied Research in Management and Economics, \\ Polytechnic Institute of Leiria, Leiria, Portugal \\ İlhami Yücel \\ Erzincan Universitesi, Erzincan, Turkey \\ Daniel Gomes \\ Instituto Politécnico de Coimbra \\ Escola Superior de Educação de Coimbra, Coimbra, Portugal
}

*Corresponding author

To cite this document:

Ribeiro, N., Yücel, I. \& Gomes, D. (2018). "How transformational leadership predicts employees' affective commitment and performance", International Journal of Productivity and Performance Management, Vol. 67 Issue: 9, pp.1901-1917, https://doi.org/10.1108/ IJPPM-09-2017-0229

Permanent link to this document:

https://doi.org/10.1108/IJPPM-09-2017-0229 


\title{
How Transformational Leadership predicts Employees' Affective Commitment and Performance
}

\begin{abstract}
Purpose - The purpose of this paper is to examine the impact of transformational leadership (TL) on employees' individual performance (IP) through the mediating role of affective commitment (AC). More specifically, it aims to understand how (a) TL relates to employees' AC, (b) TL relates to employees' IP, (c) employees' AC relates to IP and (d) employees' AC mediates the relationship between TL and employees' IP.

Design/methodology/approach - Four hundred and seventy-six Turkish healthcare professionals participated in this study. The mediation effect of $\mathrm{AC}$ in the relationship between TL and employees' IP was tested by Structural Equation Modelling (SEM).

Findings - The results indicate that AC mediates the relationship between TL and employees' IP. In others words, transformational leaders promote employees' AC which, in turn, increases their IP.

Practical implications - This study suggests that organizations should select, develop and invest in leaders who adopt a TL style because they build a climate of admiration, loyalty, respect, participation and involvement for employees which will in turn enhance their commitment and performance.

Originality/value - This study responds to calls for researches to explore the mediating mechanism in the TL process (Judge et al., 2006), as the mediation effects explain the conditions in which TL is related to the favorable outcomes.
\end{abstract}

Keywords: Transformational Leadership, Affective Commitment, Individual Performance.

Paper type Research paper 


\section{Introduction}

Transformational leadership (TL) has been considered the most influential leadership theory over the past two decades (Avolio et al., 2009; Judge and Piccolo, 2004; Sosik and Jung, 2010). TL has been defined as a set of behaviors that motivate followers to achieve performance beyond basic expectations by changing followers' attitudes, beliefs, and values (Bass, 1985; Yukl, 1999). The dynamics of TL point to followers having a strong personal identification with the leader, a shared vision for the future, and the ability to work collectively for the benefit of the team (Kelloway et al., 2003), these help followers make a positive transformation in themselves (Cetin and Kinikb, 2015). Therefore, transformational leaders inspire followers to do more in their organizations than what is required (Sosik et al., 2002).

The idea that TL plays a critical role in an organization's success is well established in leadership literature (Avolio et al., 1988; Elenkov, 2002; Wang et al. 2011; Zhu et al., 2005). A growing body of research on TL supports the suggestion that TL seems valuable, such that employees with transformational leaders demonstrate more favorable outcomes (Arnold et al., 2007; Rubin et al., 2005). For example, Limsila and Ogunlana (2008) conducted research in the construction industry in Thailand and found a positive impact of TL on employees' performance and organizational commitment. The effect of TL is particularly important for individuals who work in healthcare industries because these professionals often work in high pressure environments. Andrews and Dziegielewski (2016) stated that nursing staff generally prefer leaders with transformational behaviors that address followers' individual needs. Then, the current study aims to acknowledge the relevance of TL in enhancing the affective commitment (AC) and individual performance (IP) of staff in Turkish healthcare sector.

Organizational commitment has been linked to TL across a variety of organizational settings (Abouraia and Othman, 2017; Bono and Judge, 2003; Emery \& Bateman, 2007; Ismail \& Yusuf, 2009; Joo et al., 2012; Malik et al., 2017; Selamat et al., 2013; Top et al., 2015). Although the empirical evidence suggests that TL is positively related to organizational commitment, when considering the impact of TL on affective commitment and its role as a mediator variable in the relationship between TL and performance, very little evidence is available on literature. 
A wealth of research exists indicating that TL is positively related to performance (Avolio et al., 2012; Liao and Chuang, 2007; Nguni et al., 2006). For example, a meta-analyses of 25 years of research based on 113 primary studies has provided strong support for positive associations between TL and IP (Wang et al., 2011). This leadership style affects organizational outcomes because transformational leaders motivate and inspire followers to achieve organizational goals, so they improve their performance. Performance beyond expectations is possible only by transforming followers' values, attitudes and motives from a lower to a higher plane of arousal and maturity (Bass, 1985).

While the direct effects of TL on employees are well researched, the mediating role of AC in the relationship between TL and the employees' IP is less clear. Thus, there is the need to understand the mechanism through which TL style increases IP. Possibly, those who engage in a TL style experience more support from their followers, who individually report higher levels of AC which, in turn, lead to higher levels of IP.

The current study employed AC as the mediating variable for three reasons. First is that AC is robust with strong reliability and validity (Meyer et al., 2002). Second is that among the three dimensions of organizational commitment, the affective dimension was found to correlate the strongest with individual and organizational outcomes (Meyer et al., 2002). Third, our option constitutes an answer to a call for research on the mediating mechanism in the TL process (Judge et al., 2006), as the mediation effects explain the conditions in which TL is related to the favorable outcomes.

Despite the criticisms against TL theory, we selected this construct because it has received both theoretical and empirical support more than any other leadership theory. According to Judge and Piccolo (2004), TL expresses the highest overall validity than transactional and laissez-faire leadership styles. On the other hand, TL has been the most empirically researched construct and is viewed as an effective form of leadership at the organizational, sectoral and national levels (Gyensare et al., 2016).

Moreover, concerns have been identified at the lack of context-specific research in leadership (Jordan et al., 2010; Liden and Antonakis, 2009). Therefore, developing a study of this nature in a segment of the healthcare sector in Turkey is timely and justified.

This study addresses the mentioned gaps and aims to examine the impact of TL on 
employees' IP through the mediating role of AC. More specifically, it aims to understand how (a) TL explains employees' AC, (b) TL explains employees' IP, (c) employees' AC explains their IP and (d) employees' AC mediates the relationship between TL and employees' IP. Therefore, this research intends to integrate the above constructs into a single conceptual model and it provides to the literature a more comprehensive understanding of how TL can relate to individual performance through AC's mediating role.

The paper is structured as follows: The next section deals with the relevant literature and develops hypotheses. This is followed by section three, the research method. Section four presents the main findings. Last section analyses and discusses the findings and identifies the contributions to the literature, the implications for management, details of the study's limitations, and recommendations for future research.

\section{Research Background and Hypothesis Development}

$T L$

According to Bass and Riggio (2006), "TL is, at its core, about issues around the processes of transformation and change" (p. 255). In TL the relationship between leader and followers goes beyond the satisfaction of individual interests, building up a sense of common identity based on the collective ideal. Transformational leaders motivate followers to exceed their own interests on behalf of the interests of the group or organization. This occurs due to the trust, admiration, loyalty and respect that the followers feel for the leader. Transformational leaders provide deeper levels of connection and higher levels of commitment, performance, and morality (Burns, 1978).

TL has been conceptualized into four key factors or dimensions (Bass and Avolio, 1990; Bass et al., 2003; Bass and Riggio, 2006; Mamede et al., 2014; Rafferty and Griffin, 2004), "the four Is" of behavior (Hoch et al., 2016): (1) Idealized influence/ charisma: reflects a leader that provides vision and sense of mission, instills pride, wins the respect and trust of followers; (2) Inspirational motivation: the leader communicates high expectations, uses symbols to support efforts of the followers, expresses important purposes in simple ways and acts as a model of behaviors; (3) Intellectual stimulation: 
the leader stimulates employees to be innovative and creative, encourages in the followers consciousness for their problems, promotes intelligence, rationality and careful problem solving and (4) Individualized consideration: leaders gives personal attention, provides employees with feedback, and delegates responsibilities to them, treats each employee individually, coaches, and advises.

Even though broadly used, the conceptualization of TL in separate dimensions is problematic in the leadership literature. According to Den Hartog et al. (1997), the fourdimensional structure has not always been found. None of the individual dimensions have been clearly delineated (Mesu et al., 2015). From a theoretical perspective, the difference between idealized influence/charisma and inspirational motivation is less clear, because charismatic leaders tend to inspire people through their vision as well (Mesu et al., 2015; Rowold and Heinitz, 2007). The distinction between individualized consideration and intellectual stimulation may also be difficult because both mention employees' development (Mesu et al., 2015).

Yukl (2006) argued that results for different components of TL measure are inconsistent. $\mathrm{Fu}$ et al. (2010) revealed that the dimensions are so highly inter-correlated that it is difficult to clearly determine their separate effects, even when factor analyses support their distinctiveness. Other researchers have carried out factor analyses with onedimension scale where all dimensions loaded on one factor (Anatonakis et al., 2003; Bass and Riggio, 2006). Therefore, many studies on TL have used only the composite factor rather than the four dimensions (Gyensare et al., 2016; Mesu et al., 2015; Top et al., 2013; Yucel et al., 2014; Yukl, 2006).

Prior researchers have found the positive effect of TL on employees' attitudes and behaviors, such as job satisfaction, trust, commitment and tasks performance (Aryee et al., 2002; Avolio et al., 2004; Dhawan and Mulla, 2011; Judge and Piccolo, 2004; Sanda and Kuada, 2013) as well as negative impact on turnover intention (Dupré and Day, 2007; Gyensare et al., 2016). A TL is supposed to employ a visionary and creative style of leadership that inspires followers to make independent decisions and develop in their work (Nielsen and Munir, 2009). In sum, leadership style is a significant factor, which affects the employees' attitudes and behaviors. 


\section{TL and $A C$}

Organizational commitment refers to a psychological attachment of an individual toward an organization (Mathieu and Zajac, 1990). The literature indicates that of the three components of organizational commitment (affective, normative, and calculative), the affective commitment has more desirable outcomes for the organizations (Meyer et al., 2002). Mercurio (2015) suggests a conceptual framework in which AC is understood as the core essence of organizational commitment. AC can be described as the employee's positive emotional attachment and identification with the organization (Allen and Meyer, 1990). Employees who are affectively committed to the organization want to be part of it, since they believe in its values and objectives (Allen and Meyer, 2000). Thus, organizations must be able to develop their employees' AC (Meyer and Herscovitch, 2001).

Several studies have sought to determine the antecedents of AC (Allen and Meyer, 1996; Meyer et al., 2002; Rego et al., 2013). TL has been indicated as an important antecedent of the attachment to the organization (Shamir et al., 1993), more specifically, the literature reveals a positive relationship between TL and AC (Allen and Meyer, 1996; Bycio et al., 1995; Kark et al., 2003; Meyer et al., 2002; Podsakoff et al., 1996; Rafferty and Griffin, 2004; Yucel et al., 2014).

According to Braun et al. (2013), the identification with, and attachment to, the leader results in improved AC in the followers. Popper, Ori and Ury (1992) argue that transformational leaders have an extraordinary effect on followers and their success in establishing their commitment. A transformational leader transforms and creates meaning for the employees that promotes the AC. Thus, TL appears to be particularly associated with AC (Bass and Riggio, 2006; Kane and Tremble, 2000; Meyer et al., 2002; Penley and Gould, 1988).

Social exchange theory explains the relationship between TL and organizational commitment (Blau, 1964; Gouldner, 1960; Leroy et al., 2012). When leaders seek organizational commitment from their followers, they need to engage in behaviors that go beyond the economic exchange. Transformational leaders emphasize the individual needs and personal development of their followers, encourage subordinates to do more than the expected (Bass, 1985), underline the importance of appreciating and valuing 
subordinates (Stone et al., 2004). As a result, followers feel trust, admiration, loyalty, and respect toward transformational leaders (Yulk, 2010). In other words, these leaders transform employees by increasing motivation and commitment, and empowering them to achieve organizational goals (Yulk, 2010).

Based on the above arguments, we hypothesize:

Hypothesis 1: TL relates positively with AC.

\section{TL and employees' IP}

IP is a relevant and often used outcome measure in management research and can be defined as a set of actions and behaviors that are relevant to the goals of the organization (Campbell, 1990). Thus, it is pertinent to discover the main predictors of employees' IP. Research has traditionally tested employees' performance as a criterion variable (Bono and Judge, 2003; Quiñones et al., 1995).

Bass (1985) stated that generally transformational leaders transform their followers towards higher performance levels. Studies that test the relationship between TL and followers' performance have emerged (Biswas, 2014; Nielsen et al., 2009; Tse and Chiu, 2014; Vecchio et al., 2008). Researchers have examined the positive impact of TL on task performance (Aryee and Chu, 2012; Judge and Piccolo, 2004). Boerner et al. (2007) argued that TL related to follower performance and innovation. According to Rowald and Heinitz (2007), TL has a positive effect on employees' subjective performance and on organizational profit. The influence of TL on team performance and service quality was investigated by Lee et al. (2011). Camps and Rodriguez (2011) also found a positive relationship between TL behavior and employees' IP.

Transformational leaders induce employees to perform beyond the minimum level of organizational expectations based on a set of leadership attitudes and behaviors: motivate and appeal to subordinates' emotions, elicit respect from subordinates, support subordinates' unique developmental needs and stimulate subordinates' desire to learn and develop (Bass, 1998; Bass et al., 2003). Based on social exchange theory and the norm of reciprocity (Blau, 1964; Gouldner, 1960), these reciprocal effects between 
transformational leaders and their followers can be explained. The fundamental aspects of the exchange relationships between these leaders and followers are mutual benefits, trust, and long-term mission achievement (Turner et al., 2002).

The transformational leaders influence followers to focus on collective interest instead of self-interest (Lussier and Achua, 2007). By doing this, they are able to stimulate followers to a higher level of performance (Yulk, 2010).

Thus, we hypothesize:

Hypothesis 2: TL relates positively with employees' IP.

\section{$A C$ and Employees' IP}

Prior studies have argued that organizational commitment had a positive effect on job performance (Chen et al., 2006). For example, Yousef (2000) argued that organizational commitment is positively related to both job satisfaction and performance. Several researchers (Abdul Rashid et al., 2003; Chen et al., 2006; Riketta, 2002; Samad, 2005) found that committed employees are more likely to have higher work motivation, as well as higher job performance. Affectively committed employees tend to perform their jobs better and be more productive (Leroy et al., 2012; Meyer and Herscovitch, 2001; Meyer et al., 2002; Riketta, 2002).

Employees with higher levels of $\mathrm{AC}$ are more willing and motivated to contribute significantly towards the organization (Rego and Souto, 2004). Therefore, AC increases in-role and extra-role performance (Allen and Meyer, 1996; Jaramillo et al., 2005; Meyer et al., 2002; Riketta, 2002; Vandenabeele, 2009; Vandenberghe et al., 2004). Employees with high $\mathrm{AC}$ are more committed to contributing to organizational success, and they tend to improve their performance.

Thus, we hypothesize:

Hypothesis 3: AC is positively related with employees' IP. 
The extraordinary commitment that transformational leaders induce in their followers may inspire their great performance (Bass and Riggio, 2006). A mechanism through which TL was related to job performance includes the followers' positive emotion (Liang and Chi, 2013).

Transformational leaders respect their followers and are concerned with followers' feelings and needs (Podsakoff et al., 1990). Then, they create a friendly and psychologically supportive work environment (House, 1996) and the employees' perception of being valued and cared about by the organization influence their emotional attachment to the organization (Allen et al., 2003; Battistelli et al. 2016; Kim et al. 2016; Lee and Peccei, 2007; Lew, 2009; Sharma and Dhar, 2016). In turn, affectively committed employees tend to enhance their performance (Leroy et al., 2012; Meyer and Herscovitch, 2001; Riketta, 2002).

The study of Camps and Rodriguez (2011) found that TL increases employees' selfperceived employability, commitment, and performance. Employees who work with transformational leaders improve the self-perception of their employability and develop their commitment to their employers who have trusted and invested in them. This increase in organizational commitment leads to higher employees' performance (Camps and Rodriguez, 2011).

When employees perceive that an organization cares about their wellbeing and values their contributions (Gould-Williams, 2007; Vermeeren et al., 2011) and transformational leaders provide the necessary support to subordinates while attending to subordinates' unique developmental needs (Bass, 1998), then the employees develop their emotional attachment to organizational goals which, in turn, result in employee's willingness to exert effort on behalf of the organization. This proposition is based on an assumption that if leaders and organizations care for their workers, they in return will improve their performance, as a result of their AC.

Based on the above arguments, we hypothesize:

Hypothesis 4: AC mediates the relationship between TL and employees' IP. 


\section{Method}

\subsection{Sample and procedures}

The study comprises 476 Turkish healthcare professionals from a large hospital in a major city in eastern Turkey. Healthcare organizations have a relevant impact on society's health and well-being but they face a multitude of problems that need to be addressed by organizational leadership. By analyzing the TL of hospital leaders and the levels of healthcare employees' AC and their performance, the quality of patient care and hospital performance can be improved.

A survey was developed to collect the data, meeting the aims of the study, and assuring the anonymity and confidentiality of the participants' answers. To reduce common method biases, we have fulfilled certain criteria (Podsakoff et al., 2003), notably: (a) there was randomness in the ordering of multiple items; (b) we did not use scales with bipolar numerical values or assign verbal designations for the midpoints of the scales. The items were translated from English into Turkish by a first bilingual speaker and then independently back-translated into English by a second bilingual speaker (Brislin, 1980). The hospital's HR department provided a list of all employees and their e-mail addresses. Eight hundred and fifty questionnaires were distributed, 498 were returned and 22 of them were excluded because they were incomplete. Of the 476 respondents, 57,4\% were female and 72,5\% were aged between 25 and 44 years (s.d.=,944/ coded in the following way: $18-24 ; 25-34 ; 35-44 ; 45-55 ; \geq 55)$. With regard to the level of education, $67 \%$ are graduated (s.d.=,556/ coded in the following way: high school; graduate; post graduate).

We have taken the option of using bootstrapping (Efron, 1992). Bootstrapping brings the advantage of calculating data using $n$ replicas of our original sample, thus helping to calculate standard error, notably, in case of distributional assumptions violation (Efron \& Tibshirani, 1985). As such, using this technique provides added protection while using SEM data analysis procedures. Given the characteristics and the advantages of using bootstrapping technique in SEM models, we have made the option of using bootstrapping while calculating our data. 


\subsection{Measures}

The variables were operationalized through scales validated in the literature. Following Podsakoff and colleagues' (2003) recommendations, in order to control for the impact of common method variance, we have performed the Harman test (1967) which suggested that the data was robust to common method variance, by pointing out that a single factor did not emerge that accounted for the majority of the covariance among the measures.

Respondents were asked to indicate the level of applicability the indicators of the different measures on a seven-point Likert scale (1: does not apply to me at all; 7: applies completely to me).

The study measures TL through fifteen items proposed by Rafferty and Griffin (2004). Sample items included: "Encourages people to see changing environments as situations full of opportunities" and "Considers my personal feelings before acting”. Cronbach's alpha was ,93.

Based on relevant studies in the literature on TL (e.g., Aryee and Chu, 2012; Boerner et al., 2007; Fu et al., 2010; Gyensare et al., 2016; Mesu et al., 2015; Yucel et al., 2014; Yukl, 2006), this variable was considered an uni-dimensional construct.

The study measures AC through three items proposed by Rego et al. (2011). Sample items included: "I am proud to tell others that I am part of this organization" and "I feel like «part of the family» at my organization”. Cronbach's alpha was ,84.

To measure IP, the study uses four items from Rego and Cunha (2008). Sample items included: "I am happy with the quality of my work output" and "My manager believes I am an efficient worker”. Cronbach's alpha was ,93.

\section{Results and Analysis}

We have tested our study hypotheses with Structural Equation Modelling (SEM) using Amos software. For estimating the goodness-of-fit, we will report the Root Mean Square Error of approximation (RMSEA) (Steiger and Lind, 1980), Comparative Fit Index (CFI) (Bentler, 1990), Tucker-Lewis Index (TLI) (Tucker-Lewis, 1973) and $\chi^{2}$ values. In 
accordance with some authors (Browne and Cudeck, 1993; Hulland et al., 1996), we will consider a model with CFI and TLI values ranging from $\leq 0.90$ to $\leq 0.95$ combined with RMSEA values ranging from $\leq .10$ to .08 to be acceptable, and CFI and TLI values $\geq 0.95$ combined with RMSEA $\leq .08$ to be very good.

Table 1 presents the descriptive statistics and the correlations matrix of the model's variables. Our results provide evidence that gender and age are significantly correlated $(r=.125 ; p \leq .01)$. It is also possible to see that age and TL are also correlated with each other $(r=.10 ; p \leq .05)$, as well as education and IP $(r=.116 ; p \leq .05)$. Results also show that the variables of our analysed model are significantly correlated between themselves [TLIP $(r=.310 ; p \leq .01) /$ TL-AC $(r=.656 ; p \leq .01) /$ AC-IP $(r=.388 ; p \leq .01)]$. It is also possible to verify that IP is perceived positively in this organization (mean $=5.51$; s.d. $=1.38$ ). As for $\mathrm{AC}$, it is possible to see that workers' $\mathrm{AC}$ is placed in the middle point of the scale, evidencing some degree of indifference regarding how workers are seen as having an affective bond with the organization (mean $=4.00$; s.d. =2.02). Lastly, perceptions of TL are placed below the middle point of the scale (mean=3.58; s.d. $=1.38$ ), implying that workers may see the organization as having transformational leaders below the desirable level.

[Table 1 near here]

These results provide support for the study's first, second and third hypothesis (H1, H2 and H3). These results suggest that how the leadership style is developed and applied in the organization positively affects how workers develop an affective bond with the organization, and also how workers perform. In addition, results also provide support regarding how the affective bond with the organization is positively and significantly related with employees' performance.

Following the analysis with respect to the mediational hypothesis $(\mathrm{H} 4)$ and the goodnessof-fit of the theoretical model, results showed acceptable fit to the data $\left(\chi^{2}(57)=667.141\right.$, $p=.000 ;$ RMSEA $=.092 ;$ CFI $=.94$; TLI =.93). The single factor model revealed unacceptable fit indices $\left(\chi^{2}(54)=1970.923, p=.000 ;\right.$ RMSEA $=.169 ; \mathrm{CFI}=.77$; TLI =.75). Table 2 provides the fit indices and Figure 1 presents the Analysed Model.

[Table 2 near here] 
[Figure 1 near here]

In order to access the mediational effect if this mediation is either partial or total, we have made reference to the procedure recommended by Kenny and Judd (1984) for assessing mediational effects using SEM, and report the direct, indirect and total effects (standardized effects). Table 3 provides the standardized total, indirect and direct effects, for the purposes of testing the mediation hypothesis.

[Table 3 near here]

Results have shown that the direct effect of TL on IP is non-significant (Direct Effect $=.076 ; p>.05$ ), and the total effect on IP is significant (Total Effect $=.327 ; p \leq .01$ ), as well as the indirect effect through AC (mediator) (Indirect Effect=.251; $p \leq .01$ ). According to these results, the fourth hypothesis (H4) of our study is supported, showing a total mediation effect of AC in the relation between TL and IP.

\section{Discussion and Conclusions}

\subsection{Discussion}

The results indicate that transformational leaders induce followers' $\mathrm{AC}$ and this is consistent with other studies (Allen and Meyer, 1996; Bycio et al., 1995; Kark et al., 2003; Podsakoff et al., 1996; Meyer et al., 2002; Rafferty and Griffin, 2004; Shamir et al., 1993; Yucel et al., 2014). TL causes employees to perceive that the organization supports, values and cares them and leads to attachments among the organization's members and develop a high level of $\mathrm{AC}$ to the organization. 
This relationship should be reciprocal and it can be explained by the social exchange theory (Leroy et al., 2012). In organizations, social exchanges are relevant because they can be decisive regarding organizational and individual performance. They can be used to explain the link between employee perceptions of workplace aspects and their subsequent attitudes and behaviours. These exchanges are characterised by co-operation and reciprocity, that is, when one partner provides a benefit to another, the act produces a sense of obligation on the part of the latter to reciprocate at some point in the future. Specifically, based on the norm of reciprocity, transformational leaders, through inspiration and high expectations they have for employees, their vision for the organization and the support they provide that fosters social support, teamwork, selfactualization, and goal achievement, they thus increased levels of commitment among employees (Simosi and Xenikou, 2010). Therefore, employees who develop high quality exchanges with their transformational leaders reciprocate by displaying positive attitudes, such as, AC.

In the same vein, TL may be an effective mechanism to improve employees' IP as shown by our results and literature reviewed (Biswas, 2014; Camps and Rodriguez, 2011; Nielsen et al., 2009; Tse and Chiu, 2014; Vecchio et al.,2008; Yulk, 2010). Employees who work under transformational leaders understand the organizational vision and mission very clearly and consequently perform better (Avolio, 1999). Such leaders enhance employees' expectations and recognition of their work and increase employees' IP through TL behaviors such as individual attention, inspiration, intellectual stimulation, and motivation.

This relationship can be understood as a reciprocal exchange because employees become committed to producing better job outcomes when they are valued by leaders. In other words, if the employees receive important and valuable leader's support, driven by a sense of obligation, and based on the principle of mutual benefit, not only do they reveal AC, they also show enhanced performance to help the organization to achieve its goals.

The current study reveals a full mediation of $\mathrm{AC}$ in the relationship between TL and employees' IP. It suggests that transformational leaders adopt behaviors that motivate followers to perform and identify with organizational goals and interests and have the capacity to motivate employees beyond expected levels of work performance. As a result, employees feel affectively committed and personally rewarded through work, and their 
performance is enhanced.

In sum, transformational leaders through charisma, inspirational motivation, intellectual stimulation and individualized consideration, create an environment where employees develop a sense of organizational identification and have more a positive leader-member exchange relationship. Also employees should be more affectively to the organization, more satisfied, and more productive (Hendrix et al., 2015).

\subsection{Limitations and Future Studies}

This study presents several limitations. First, TL, AC and IP were measured from the same individuals using the same questionnaire at a single time. This raises the risk of introducing common method variance (Podsakoff et al., 2003). To address this concern, some preventative methods were undertaken, such as the Harman test and other procedures described earlier. Future research may explore the effect of TL on subordinate outcomes using longitudinal designs or via a multiple-source method. Second, the study included only one mediating variable, but others are plausible. For example, it is possible that TL develops wellbeing and engagement which in turn, increases employees' performance. Third, moderating variables were not included. Future research may test, for example, the degree to which some personal characteristics moderate the relationships between TL and the dependent variables. Moreover, future studies, particularly experimental studies, may explore these effects under a variety of task scenarios. The different scenarios can be used to explore the effects of TL on subordinate outcomes moderated by other variables.

\subsection{Theoretical Contributions}

From a theoretical perspective, the present study confirms the results of prior studies that found positive effects of TL on employees' AC and performance (Biswas, 2014; Camps and Rodriguez, 2011; Kark et al., 2003; Meyer et al., 2002; Nielsen et al., 2009; Rafferty and Griffin, 2004; Tse and Chiu, 2014; Vecchio et al., 2008; Yucel et al., 2014; Yulk, 2010). Therefore, the current findings support theoretical results that suggest the quality of relationships between leaders and followers may play an important role in the extent to which followers develop positive attitudes and behaviors. 
This study answers the call for further research from those who have argued that more information is needed to understand the process through which TL influences employees' performance (Avolio et al., 2009). Then, the present research sought to integrate TL, AC and individual performance into a single conceptual model. It also constitutes an answer to a call for research on the mediating mechanism in the TL process (Judge et al., 2006), as the mediation effects explain the conditions in which TL is related to the favorable outcomes. Therefore, this study addressed significant research gaps by testing the relevant variables' mediating effects. It provides a more comprehensive understanding of how TL can relate to individual performance through AC's mediating role.

\subsection{Implications for management}

This study makes a significant practical contribution by providing advice to leaders and organizations on how to create an atmosphere of admiration, loyalty, respect, participation and involvement for employees which will in turn help to enhance their commitment and performance. Therefore, organizations must seek those with TL ability because they bring special assets to their organizations.

With this knowledge, organizations should select, develop and invest in leaders who adopt a TL style. These leaders (1) communicate a compelling vision, (2) provide symbols and emotional appeals to increase awareness of mutual goals, (3) develop team spirit in followers, (4) facilitate the efforts of followers to become more innovative and creative, (5) stimulate followers to adopt new work perspectives, (6) provide a supportive climate, (7) listen to the individual needs of the followers, (8) treat followers with respect, (8) facilitate individual growth by inspiring, coaching, teaching, mentoring and (10) delegate to help followers achieve their tasks and grow through individual challenges.

In sum, developing positive leadership styles (such as TL) and improving employee attitudes (such as AC) are important strategies to promote employees' performance. Results of this research were expected to be beneficial to the management of healthcare services in showing that the TL style used by supervisors might engender a sense of AC among healthcare staff that would lead to a performance improvement. 


\section{References:}

Abdul Rashid, M.Z., Sambasivan, M. and Johari, J. (2003), "The influence of corporate culture and organizational commitment on performance", Journal of Management Development, Vol.22 No. 8, pp. 708-728.

Abouraia, M. K. and Othman, S. M. (2017), “Transformational Leadership, Job Satisfaction, Organizational Commitment, and Turnover Intentions: The Direct Effects among Bank Representatives", American Journal of Industrial and Business Management, Vol. 7, pp. 404-423.

Allen, D. G., Shore, L. M. and Griffeth, R. W. (2003), “The role of perceived organizational support and supportive human resource practices in the turnover process", Journal of Management, Vol. 29 No. 1, pp. 99-118.

Allen, N. J. and Meyer, J. P. (1996), “Affective, continuance, and normative commitment to the organization: An examination of construct validity", Journal of Vocational Behavior, Vol. 43 No. 3, pp. 252-276.

Allen, N. J. and Meyer, J. P. (1990), “The measurement and antecedents of affective, continuance and normative commitment to the organization", Journal of Occupational Psychology, Vol. 63 No. 1, pp. 1-18.

Allen, N. J., and Meyer, J. P. (2000), “Construct validation in organizational behavior research: The case of organizational commitment”, In R. D. Goffin and E. Helmes (Eds.), Problems and solutions in human assessment: Honoring Douglas N. Jackson at Seventy, Kluwer, Norwell, MA, pp. 285-314.

Andrews, R. and Dziegielewski, S. F. (2005), “The nurse manager: job satisfaction, the nursing shortage and retention", Journal of Nursing Management, Vol. 13 No. 4, pp. 286-95.

Arnold, K. A., Turner, N., Barling, J., Kelloway, E. K. and McKee, M. C. (2007), "Transformational leadership and psychological well-being: the mediating role of meaningful work", Journal of Occupational Health Psychology, Vol. 12, pp. 193-203. 
Aryee, S. and Chu, C.W.L. (2012), “Antecedents and outcomes of challenging job experiences: a social cognitive perspective", Human Performance, Vol. 25 No. 3, pp. 215-234.

Aryee, S., Walumbwa F. O., Zhou Q. and Hartnell C. A. (2002), "Transformational leadership, innovative behavior, and task performance: Test of mediation and moderation processes", Human Performance, Vol. 25, pp. 1-25.

Avolio, B. J. (1999). Full leadership development: Building the vital forces in organizations, Sage, Thousand Oak, CA.

Avolio, B. J., Sosik, J. J., and Berson, Y. (2012), "Leadership models, methods, and applications: Progress and remaining blind spots", In I. B. Weiner, (Ed), N W. Schmitt and S. Scott Highhouse (Vol. Eds.), Handbook of psychology: Industrial and organizational psychology (2nd ed.), Wiley, Somerset, NJ, pp. 367-389.

Avolio, B. J., Walumbwa, F. O., and Weber, T. J. (2009), "Leadership: current theories, research, and future directions", Annual Review of Psychology, Vol. 60, pp. 421-449.

Avolio, B., Gardner, W., Walumbwa, F.O, Luthans, F. and May, D.R. (2004), "Unlocking the mask: A look at the process by which authentic leaders impact follower attitudes and behaviors", Leadership Quarterly, Vol. 15, pp. 801-823.

Avolio, B.J., Waldman, D.A. and Einstein, W.O. (1988), “Transformational leadership in a management game simulation: Impacting the bottom line", Journal of Group and Organizational Studies, Vol. 13 No. 1, pp. 58-80.

Bass, B. M. (1985), Leadership and performance beyond expectations, The Free Press, New York, NY.

Bass, B. M. (1998), Transformational leadership: Industry, military, and educational impact, Erlbaum, Mahwah, NJ.

Bass, B. M. and Riggio, R. E. (2006), Transformational leadership, Lawrence Erlbaum Associates, Mahwah, NJ. 
Bass, B. M., Avolio, B. J., Jung, D. I. and Berson, Y. (2003), "Predicting unit performance by assessing transformational and transactional leadership", Journal of Applied Psychology, Vol. 88 No. 2, pp. 207.

Bass, B.M. and Avolio, B.J. (1990), "Training and development of Transformational leadership: Looking to 1992 and beyond”, European Journal of Industrial Training, Vol. 14, pp. 21-27.

Bass, B.M. and B.J. Avolio, (2000), Multifactor Leadership Questionnaire, 2nd Ed., Mind Garden, Redwood City, CA.

Battistelli, A., Galletta, M., Vandenberghe, C. and Odoardi, C. (2016), "Perceived organizational support, organizational commitment and self-competence among nurses: a study in two Italian hospitals", Journal of Nursing Management, Vol. 24 No. 1, pp. 44-51.

Bentler, P. (1990), "Comparative fit indexes in structural models", Psychological Bulletin, Vol. 107, pp. 238-246.

Biswas, S. (2014), “Organizational Culture \& Transformational leadership as Predictors of Employee Performance. Indian Journal of Industrial Relations”, Vol. 44 No. 4, pp. 611-627.

Blau, P. M. (1964), Exchange and power in social life, John Wiley, New York, NY.

Boerner, S., Eisenbeiss, S. A. and Griesser, D. (2007), "Follower Behavior and Organizational Performance: The Impact of Transformational Leaders", Journal of Leadership \& Organizational Studies, Vol. 13 No. 3, pp. 15-26.

Bono, J. E. and Judge, T. A. (2003), "Core self-evaluations: A review of the trait and its role in job satisfaction and job performance", European Journal of Personality, Vol. 17, pp. 5-18.

Braun, S., Peus, C., Weisweiler, S. and Frey, D. (2013), “Transformational leadership, job satisfaction, and team performance: A multilevel mediation model of trust", Leadership Quarterly, Vol. 24, pp. 270-283. 
Brislin, R.W. (1980), "Translation and content analysis of oral and written materials", in Triandis, H. C. and Berry, J.W. (Eds.), Handbook of Cross-Cultural Psychology, Vol. 2, Allyn and Bacon, Boston, MA, pp. 389-444.

Browne, M. W. and Cudeck, R. (1993), “Alternative ways of assessing model fit" In K. A. Bollen and J. S. Long (Eds.), Testing structural equation models, Sage, Newbury Park, CA, pp. 136- 162.

Burns, J. M. (1978). Leadership, Harper \& Row, New York, NY.

Bycio, P., Hackett, R. D. and Allen, J. S. (1995), "Further assessments of Bass's (1985) conceptualization of transactional and transformational leadership", Journal of Applied Psychology, Vol. 80, pp. 468-478.

Campbell, J. (1990), "Modeling the performance prediction problem in industrial and organizational psychology", in Dunnette, M. and Hough, L. (Eds) Handbook of Organizational and Industrial Psychology, Consulting Psychologists Press, Palo Alto, CA, pp. 687-732.

Camps, J. and Rodriguez, H. (2011), “Transformational leadership, learning, and employability: effects on performance among faculty members", Personnel Review, Vol. 40 No. 4, pp. 423-442.

Cetin, M. O. and Kinikb, F. S. (2015), “An analysis of academic leadership behavior from the perspective of Transformational leadership", Procedia - Social and Behavioral Sciences, Vol. 207, pp. 519 - 527.

Chen, J., Silverthorne, C. and Hung, J. (2006), “Organization communication, job stress, organizational commitment, and job performance of accounting professionals in Taiwan and America", Leadership \& Organization Development Journal, Vol. 27 No. 4, pp. 242-249.

Den Hartog, D. N., Van Muijen, J. J. and Koopman, P. L. (1997), “Transactional versus Transformational leadership: An analysis of the MLQ", Journal of Occupational and Organizational Psychology, Vol. 70 No. 1, pp. 19-34. 
Dhawan, V. and Mulla, Z. R. (2011), "The role of pay and leadership in developing organizational commitment", South Asian Journal of Management, Vol. 18 No. 2, pp. $60-75$.

Dupré, K.E. and Day, A.L. (2007), “The effects of supportive management and job quality on the turnover intentions and health of military personnel", Human Resource Management, Vol. 46 No. 2, pp. 185-201.

Efron, B. (1992), "Bootstrap methods: Another look at the jackknife”, in Kotz, S. and Johnson, N. L. (Eds) Breakthroughs in statistics, Springer, New York, NY, pp. pp. 569 593.

Efron, B. and Tibshirani, R. (1985), “The bootstrap method for assessing statistical accuracy", Behaviormetrika, Vol. 17 No. 1, pp. 1-35.

Elenkov, D. S. (2002), "Effects of leadership on organizational performance in Russian Companies", Journal of Business Research, Vol. 55, pp. 467-480.

Emery, C. R. and Bateman, K. J. (2007), “The effect of transactional and transformational leadership styles on the organizational commitment and job satisfaction of customer contact personnel”, Journal of Organizational Culture, Communications \& Conflict, Vol. 11 No. 1, pp. 77-90.

Fu, P., Tsui, A., Liu, J. and Li, L. (2010), "Pursuit of whose happiness? Executive leaders' transformational behaviors and personal values", Administrative Science Quarterly, Vol. 55, pp. 222-254.

Gouldner, A. W. (1960), “The norm of reciprocity: A preliminary statement”, American Sociological Review, Vol. 25, pp. 161-178.

Gould-Williams, J.S. (2007), "HR practices, organizational climate and employee outcomes: evaluating social exchange relationships in local government", International Journal of Human Resource Management, Vol. 18 No. 9, pp. 1627-1647. 
Gyensare, M. A., Winneba, Anku-Tsede, O., Sanda, M. and Okpoti, A. O. (2016), "Transformational leadership and employee turnover intention: The mediating role of AC”, World Journal of Entrepreneurship, Management and Sustainable Development, Vol. 12 No. 3, pp. 243-266.

Harman, H. H. (1967), Modern Factor Analysis, University of Chicago Press, Chicago, IL.

Hendrix, W., Born, D. and Hopkins, S. (2015), "Relationship of Transformational leadership and Character with Five Organizational Outcomes", The Journal of Character \& Leadership Integration, Vol. 3 No. 1, pp. 54-72.

Hoch, J. E., Bommer, W., H., Dulebohn, J. H. and Wu, D. (2016), "Do Ethical, Authentic, and Servant Leadership Explain Variance above and Beyond Transformational leadership? A Meta-Analysis", Journal of Management, Vol. 44 No. 2, pp. 501-529.

House, R. J. (1996), "Path-goal theory of leadership: Lessons, legacy, a reformulated theory", Leadership Quarterly, Vol. 7 No. 3, pp. 323-353.

Hulland, J., Chow, Y. and Lam, S. (1996), "Use of causal models in marketing research: A review", International Journal of Research in Marketing, Vol. 13, No. 2, pp. 181197.

Ismail, A. and Yusuf, M. H. (2009), "The Relationship between Transformational Leadership, Empowerment and Organizational Commitment: a Mediating Model Testing”, Timisoara Journal of Economics, Vol. 2 No. 6, pp. 101-110

Jaramillo, F., Mulki, J. P. and Marshall, G. W. (2005), “A meta-analysis of the relationship between organizational commitment and salesperson job performance: 25 years of research", Journal of Business Research, Vol. 58, pp. 705-714.

Joo, B. K., Yoon, H. J. and Jeung, C. W. (2012), “The effects of core self-evaluations and transformational leadership on organizational commitment", Leadership and Organization Development Journal, Vol. 33 No. 6, pp. 564-582. 
Jordan, P.J., Dasborough, M.T., Daus, C.S. and Ashkanasy, N.M. (2010), “A call to context”, Industrial and Organizational Psychology, Vol. 3 No. 2, pp. 145-148.

Judge, T. A., Woolf, E. F., Hurst, C. and Livingston, B. (2006), "Charismatische und transformationale Führung: Ein Überblick und eine Agenda für zukünftige

Forschungsarbeiten" [Charismatic and Transformational leadership: A review and an agenda for future research], Zeitschrift für Arbeits und Organizations Psychologie, Vol. 50 No. 4, pp. 203-214.

Judge, T.A. and Piccolo, R.F. (2004), "Transformational and transactional leadership: a meta-analytic test of their relative validity", Journal of Applied Psychology, Vol. 89 No. 1, pp. 755-768.

Kane, T.D. and Tremble, T.R. (2000), “Transformational leadership effects at different levels of the army", Military Psychology, Vol. 12 No. 2, pp. 137-160.

Kark, R., Shamir, B. and Chen, G. (2003), "The two faces of transformational leadership: Dependence and empowerment", Journal of Applied Psychology, Vol. 88, pp. 243-255.

Kelloway, E.K., Barling, J., Kelley, E., Comtois, J. and Gatien, B. (2003), "Remote Transformational leadership", Leadership \& Organization Development Journal, Vol. 24 No. 3 pp. $163-171$.

Kenny, D. A. and Judd, C. M. (1984), "Estimating the nonlinear and interactive effects of latent variables", Psychological Bulletin, Vol. 96, pp. 201-210.

Kim, S.-M., Um, K.-H., Kim, H. Y. and Kim, Y.-H. (2016), "Hospital career management system sand their effects on the psychological state and career attitudes of nurses”, Service Business, Vol. 10 No. 1, pp. 87-112.

Lee, J., and Peccei, R. (2007), "Perceived organizational support and AC: the mediating role of organization-based self-esteem in the context of job insecurity", Journal of Organizational Behavior, Vol. 28 No. 6, pp. 661-685. 
Lee, P.K.C., Cheng, T.C.E., Yeung, A.C.L. and Lai, K. (2011), “An empirical study of Transformational leadership, team performance and service quality in retail banks", Omega, Vol. 39 No. 3, pp. 690-701.

Lew, T. Y. (2009), “The Relationships between Perceived Organizational Support, Felt Obligation, Affective Organizational Commitment and Turnover Intention of Academics working with Private Higher Educational Institutions in Malaysia", European Journal of Social Sciences, Vol. 9 No. 1, pp. 72-87.

Leroy, H., Palanski, M. E. and Simons, T. (2012), “Authentic leadership and behavioral integrity as drivers of follower commitment and performance", Cornell University, School of Hospitality Administration, available at: http://scholarship.sha.cornell.edu/articles/723 (accessed 6th June, 2017).

Liang, S.-G. and Chi, S.-C. S. (2013), "Transformational leadership and follower task performance: The role of susceptibility to positive emotions and follower positive emotions", Journal of Business and Psychology, Vol. 28 No. 1, pp. 17-29.

Liao, H. and Chuang, A. C. (2007), "Transforming service employees and climate: A multisource examination of Transformational leadership in building long-term service relationships", Journal of Applied Psychology, Vol. 92, pp. 1006-1019.

Liden, R.C. and Antonakis, J. (2009), "Considering context in psychological leadership research”, Human Relations, Vol. 62 No. 11, pp. 1587-1605.

Limsila, K. and Ogunlana, S.O. (2008), "Performance and leadership outcome correlates of leadership styles and subordinate commitment", Engineering, Construction and Architectural Management, Vol. 15 No. 2, pp. 164-184.

Lussier, R.N. and Achua, C.F. (2007), Effective Leadership, 3rd ed., Thomson SouthWestern, $\mathrm{OH}$.

Malik, W. U., Javed, M. and Hassan, S. T. (2017), "Influence of Transformational Leadership Components on Job Satisfaction and Organizational Commitment", Pakistan Journal of Commerce and Social Sciences, Vol. 11 No. 1, pp. 146-165. 
Mamede, C., Ribeiro, N., Gomes, D. and Rego, A. (2014), 'Leader's moral intelligence and employees' affective commitment: the mediating role of transformational leadership", Proceedings of XXIV Jornadas Luso-Espanholas de Gestão Científica, ESTG-IPL, 6, 7 e 8 de Fevereiro, Leiria, Portugal.

Mathieu, J.E. and Zajac, D.M. (1990), "A review and meta-analysis of the antecedents, correlates, and consequences of organizational commitment", Journal of Applied Psychology, Vol. 108 No. 2, pp. 171-194.

Mercurio, Z.A. (2015), “Affective commitment as a core essence of organizational commitment: an integrative literature review", Human Resource Development Review, Vol. 14 No. 4, pp. 389-414.

Mesu, J., Sanders, K. and Riemsdijk, M. (2015), “Transformational leadership and organizational commitment in manufacturing and service small to medium-sized enterprises: The moderating effects of directive and participative leadership", Personnel Review, Vol. 44 No. 6, pp. 970-990.

Meyer, J. P. and Herscovitch, L. (2001), “Commitment in the workplace: Toward a general model”, Human Resource Management Review, Vol. 11, pp. 299-326.

Meyer, J. P., Stanley, D. J., Herscovitch, L. and Topolnytsky, L. (2002), “Affective, continuance, and normative commitment to the organization: A meta-analysis of antecedents, correlates, and consequences", Journal of Vocational Behavior, Vol. 61 No. 1, pp. 20-52.

Nguni, S., Sleegers, P. and Denessen, E. (2006), “Transformational and transactional leadership effects on teachers' job satisfaction, organizational commitment, and organizational citizenship behavior in primary schools: the Tanzanian case", School Effectiveness and School Improvement, Vol. 17 No. 2, pp. 145-177.

Nielsen, K., Yarker, J., Randall, R. and Munir, F. (2009), "The mediating effects of team and self-efficacy on the relationship between Transformational leadership, and job satisfaction and psychological well-being in healthcare professionals: A cross-sectional questionnaire survey", International Journal of Nursing Studies, Vol. 46 No. 9, pp. 1236-1244. 
Nielsen, K. and Munir, F. (2009), "How do transformational leaders influence followers' affective well-being? Exploring the mediating role of self-efficacy", Work \& Stress, Vol. 23 No. 4, pp. 313-29.

Penley, L.E. and Gould, S. (1988), “Etzioni’s model of organizational involvement: a perspective for understanding commitment to organizations", Journal of Organizational Behavior, Vol. 9 No. 1, pp. 43-59.

Podsakoff, P. M., MacKenzie, S. B., and Bommer, W. H. (1996), "Meta-analysis of the relationships between Kerr and Jermier's substitutes for leadership and employee job attitudes, role perceptions, and performance", Journal of Applied Psychology, Vol. 81 No. 4 , pp. 380-399.

Podsakoff, P. M., MacKenzie, S. B., Moorman, R. H. and Fetter, R. (1990), "Transformational leader behaviors and their effects on followers' trust in leader, satisfaction, and organizational citizenship behaviors", Leadership Quarterly, Vol. 1 No. 2, pp. 107-142.

Podsakoff, P., MacKenzie, S., Lee, J. and Podsakoff, N. (2003), “Common method biases in behavioral research: a critical review of the literature and recommended remedies", Journal of Applied Psychology, Vol. 88, No. 5, pp. 879-903.

Popper, M., Ori, L. and Ury, M. G. (1992), “The Israeli defense forces: an example of Transformational leadership \& organizational development", Leadership and Organizational Development Journal, Vol. 13 No. 1, pp. 3-8.

Preacher, K., Rucker, D. and Hayes, A. (2007), “Addressing moderated mediation hypotheses: Theory, methods, and prescriptions", Multivariate Behavioral Research, Vol. 42, pp. 185-227.

Quiñones, M. A., Ford, J. K. and Teachout, M. S. (1995), “The relationship between work experience and job performance: A conceptual and meta-analytic review", Personnel Psychology, Vol. 48 No. 4, pp. 887-910.

Rafferty, A. E. and Griffin, M. A. (2004), “Dimensions of Transformational leadership: Conceptual and empirical extensions", Leadership Quarterly, Vol. 15, pp. 329-354. 
Rego, A. and Cunha, M. P. (2008), "Perceptions of authentizotic climates and employee happiness: pathways to IP?", Journal of Business Research, Vol. 61 No. 7, pp. 739-752.

Rego, A. and Souto S. (2004), “Comprometimento organizacional em organizações autentizióticas: Um estudo luso-brasileiro" [Organizational commitment in authentizotics organizations], Revista de Administração de Empresas, Vol. 44 No. 3, pp. $30-43$.

Rego, A., Ribeiro, N., Cunha, M. P. and Jesuíno, J. C. (2011), "How happiness mediates the organizational virtuousness and AC relationship", Journal of Business Research, Vol. 64 No. 5, pp. 524-532.

Rego, A., Vitória, A., Magalhães, A., Ribeiro, N. and Cunha, M. P. (2013), “Are authentic leaders associated with more virtuous, committed and potent teams?" The Leadership Quartetly, Vol. 24, pp. 61-79.

Riketta, M. (2002), “Attitudinal organizational commitment and job performance: A meta-analysis", Journal of Organizational Behavior, Vol. 23, pp. 257-266.

Rowald, J. and Heinitz, K. (2007), “Transformational and charismatic leadership: assessing the convergent, divergent and criterion validity of the MLQ and the CKS", The Leadership Quaterly, Vol. 18 No. 2, pp. 121-133.

Rubin, R.S., Munz, D.C. and Bommer, W.H. (2005), "Leading from within: the effects of emotion recognition and personality on Transformational leadership behavior", Academy of Management Journal, Vol. 48 No. 5, pp. 845-858.

Samad, S. (2005), "Unraveling the organizational commitment and job performance relationship: exploring the moderating effects of job satisfaction", The Business Review, Vol. 4 No. 2, pp. 79-84.

Sanda, M.-A.and Kuada, J.E. (2013), "Identification ofeffective leadership indicators inGhanaian retail banks using AMOS based confirmatory factor analysis", Proceedings of the International Conference on Business Administration, Marketing and Economics, Venice, September 28-30. 
Selamat, N., Nordin, N. and Adnan, A. A. (2013), "Rekindle Teacher's Organizational Commitment: The Effect of Transformational Leadership Behavior", Procedia - Social and Behavioral Sciences, Vol. 90, pp. 566-574.

Shamir, B., House, R. J. and Arthur, M. B. (1993), "The motivational effects of charismatic leadership: A self-concept based theory", Organization Science, Vol. 4 No. 4, pp. 577-594.

Sharma, J. and Dhar, R. L. (2016), "Factors influencing job performance of nursing staff: Mediating role of AC", Personnel Review, Vol. 45 No. 1, pp.161-182.

Simosi, M. and Xenikou, A. (2010), "The role of organizational culture in the relationship between leadership and organizational commitment: an empirical study in a Greek organization", The International Journal of Human Resource Management, Vol. 21 No. 10, pp. 1598-1616.

Sosik, J. J. and Jung, D. I. (2010), Full range leadership development: Pathways for people, profits, and planet, Routledge, New York, NY.

Sosik, J. J., Avolio, B. J. and Jung, D. I. (2002), "Beneath the mask: Examining the relationship of self-presentation attributes and impression management to charismatic leadership, Leadership Quarterly, Vol. 13, pp. 217-242.

Steiger, J.H. and Lind, J.C. (1980), "Statistically-based tests for the number of common factors", Paper presented at the Annual Spring Meeting of the Psychometric Society, Iowa City.

Stone, A.G., Robert F. Russell, R.F., and Patterson, K. (2004). "Transformational versus servant leadership: a difference in leader focus", Leadership \& Organization Development Journal, Vol. 25 No.4, pp. 349-361.

Top, M., Akdere, M. and Tarcan, M. (2015), “Examining Transformational leadership, Job Satisfaction, Organizational Commitment and Organizational Trust in Turkish Hospitals: Public Servants versus Private Sector Employees", The International Journal of Human Resource Management, Vol. 26, pp. 1259-1282. 
Top, M., Tarcan, M., Tekingündüz, S. and Hikmet, N. (2013), “An analysis of relationships among transformational leadership, job satisfaction, organizational commitment and organizational trust in two Turkish hospitals", The International Journal of Health Planning and Management, Vol. 28 No. 3, pp. 217-241.

Tse, H. H. M. and Chiu, W. C. K. (2014), “Transformational leadership and job performance: A social identity perspective", Journal of Business Research, Vol. 67 No. 1, pp. 2827-2835.

Tucker, L.R and Lewis, C. (1973), “A reliability coefficient for maximum likelihood factor analysis", Psychometrika, Vol. 38, pp. 1-10.

Turner, N., Barling, J., Epitropaki, O., Butcher, V. and Milner, C. (2002), “Transformational leadership and moral reasoning", Journal of Applied Psychology, Vol. 87, pp. 304-311.

Vandenabeele, W. (2009), “The mediating effect of job satisfaction and organizational commitment on self-reported performance: more robust evidence of the PSM performance relationship", International Review of Administrative Sciences, Vol. 75, pp. 11-34.

Vandenberghe, C., Bentein, K. and Stinglhamber, F. (2004), “Affective commitment to the organization, supervisor, and work group: Antecedents and outcomes", Journal of Vocational Behavior, Vol. 64 No. 1, pp. 47-71.

Vecchio, R. P., Justin, J. E. and Pearce, C. L. (2008), “The Utility of Transactional and Transformational leadership for Predicting Performance and Satisfaction Within a Path Goal Theory Framework", Journal of Occupational and Organizational Psychology, Vol. 81 No. 1, pp. 71-82.

Vermeeren, B., Kuiprs, B. and Steijn, B. (2011), "Does leadership style make a difference? Linking HRM, job satisfaction, and organizational performance", Review of Public Personnel Administration, Vol. 34 No. 2, pp. 174-195. 
Wang, G., Oh, I.-S., Courtright, S. H. and Colbert, A. E. (2011), "Transformational leadership and performance across criteria and levels: A meta-analytic review of 25 years of research, Group \& Organization Management, Vol. 36 No. 2, pp. 223-270.

Yousef, D.A. (2000), “Organizational commitment: a mediator of the relationships of leadership behavior with job satisfaction and performance in a non-Western country", Journal of Managerial Psychology, Vol. 15, pp. 6-24.

Yucel, I., McMillan, A. and Richard, O. C. (2014), "Does CEO Transformational leadership influence top executive normative commitment?", Journal of Business Research, Vol. 67 No. 6, pp. 1170-1177.

Yukl, G. (1999), “An evaluation of conceptual weaknesses in transformational and charismatic leadership theories", Leadership Quarterly, Vol. 10 No. 2, pp. 285-305.

Yukl, G. (2006), Leadership in Organizations, 6th ed., Pearson/Prentice Hall, Upper Saddle River, NJ.

Yukl, G. (2010), Leadership in Organizations, 7th ed., Pearson/Prentice Hall, Upper Saddle River, NJ.

Zhu, W., Chew, I. K. H. and Spangler, W. D. (2005), “CEO Transformational leadership and Organizational Outcomes: The Mediating Role of Human-CapitalEnhancing Human Resource Management”, Leadership Quarterly, Vol. 16, pp. 39-52. 
Table 1. Correlation Matrix, Means and Standard Deviations

\begin{tabular}{lcccccccc}
\hline & Mean & S.D & Gender & Age & Edu. & TL & AC & IP \\
\hline Gender & - & - & 1 & & & & & \\
Age & - & - & $.125^{* *}$ & 1 & & & & \\
Education & - & - & -.058 & .036 & 1 & & & \\
Transf. Leadership (TL) & 3.58 & 1.47 & -.030 & $-.10^{*}$ & .067 & $(.93)$ & & \\
Affective Commitment (AC) & 4.00 & 2.02 & -.005 & -.090 & .042 & $.656^{* *}$ & $(.84)$ & \\
Individual Performance (IP) & 5.51 & 1.38 & -.002 & -.015 & $.116^{*}$ & $.310^{* *}$ & $.388^{* *}$ & $(.93)$
\end{tabular}

${ }^{* *} p \leq .01 ; * p \leq .05 ;$ Cronbach Alpha reported in parenthesis

Gender: 0 for female; 1 for male

Age: 1 for $18-24$; 2 for $25-34$; 3 for $35-44$; 4 for $45-55$; 5 for $\geq 55$

Education: 1 for high school; 2 for graduate; 3 for post graduate.

Table 2. Fit indices

\begin{tabular}{lcccc}
\hline & $\chi 2(\mathrm{df})$ & RMSEA & TLI & CFI \\
\hline Model 1 Theoretical model & $667.141(57) ; p=.000$ & 0.092 & 0.93 & 0.94 \\
Model 2 Single-factor model & $1970.923(54) ; p=.000$ & 0.169 & 0.75 & 0.77 \\
\hline
\end{tabular}

Table 3. Theoretical Model's standardized total, indirect and direct effects

\begin{tabular}{cccc}
\hline Path & $\begin{array}{c}\text { Total Effect } \\
\text { (T.E.) }\end{array}$ & $\begin{array}{c}\text { Indirect Effect } \\
\text { (I.E.) }\end{array}$ & $\begin{array}{c}\text { Direct Effect } \\
\text { (D.E.) }\end{array}$ \\
\hline Transf. Lead. (TL) - Ind. Perform. (IP) & $.327 * *$ & $.251^{* *}$ & .076 \\
\hline$* * p \leq .01$ & & &
\end{tabular}


Figure 1. Analysed Model

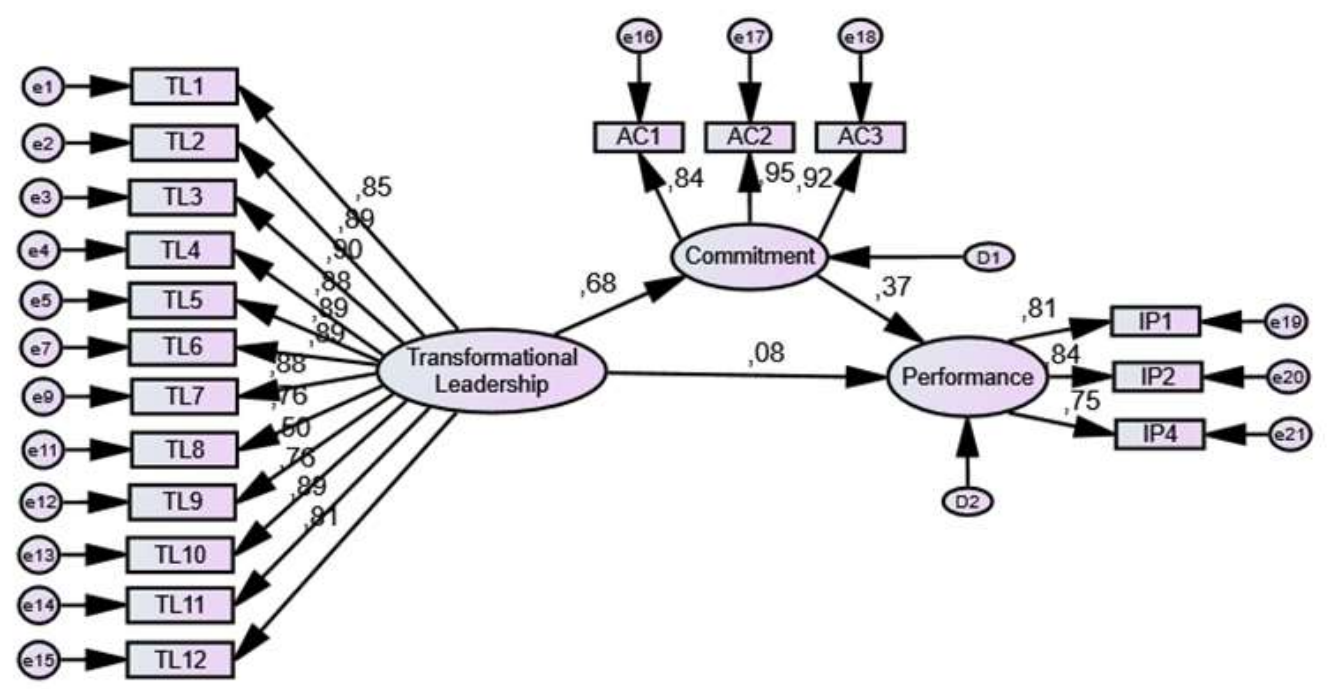

